\title{
Saçlı Hücreli Lösemi Tedavisinde Kladribinin Prognoza Etkisi
}

\author{
Cladribine Treatment in Hairy Cell Leukemia
}

\author{
Senem MARAL, Murat ALBAYRAK, Hacer Berna AFACAN ÖZTÜRK, Abdulkerim YILDIZ, Pinar \\ CÖMERT, Buğra SAĞLAM, Mesut TIĞLIOĞLU, Merih Reis ARAS
}

Ankara Dışkapı Yıldırım Beyazıt Eğitim Araştırma Hastanesi, Hematoloji Bölümü, Ankara

$\ddot{\text { Öz }}$

Saçlı hücreli lösemi (SHL) nadir görülen kronik lenfoproliferatif hastalıklar arasında yer alan, relaps ve remisyonlar ile seyreden indolent bir lenfomadır. Tedavisinde pürin analoğu (PA) kullanımı ile hastaların prognoz ve sağ kalımında önemli gelişmeler kaydedilmiștir. Bu çalışmamızda ilk basamakta kullanılan purin analogu tedavisinin iki farklı protokol ile verilmesinin nüks ve sağ kalım üzerine etkisini araştırdık. Kliniğimizde 2009-2019 yılları arasında SHL nedeniyle PA ile tedavi edilen 20 vakay1 retrospektif olarak inceledik. Bunlardan tek siklus PA uygulanan hastalar ile iki siklüs ardıșı PA tedavisi alan hasta gruplarını tanı anındaki klinik özellikleri, laboratuvar bulguları yanıt ve nüks oranları açısından karşılaştırdık. Her iki grupta yanit oranları eșit olmakla birlikte, ilk basamak tedaviye tam yanıt oranı $\% 90$, kısmı yanıt oranı $\% 10$ olarak değerlendirilmiștir. Hastalarımızın median takip süresi 69 aydır ve bu süre içerisinde her iki gruptan birer hastada nüks izlenmiştir. Tek siklus tedavi alan hastalardan 1 tanesi hastalık dışı nedenle eks olmuştur. Ardışık iki siklus 2Cd-A uygulanmasının yanıt ve nüks oranı ilişkili üstünlüğü gösterilememiștir. İlk basamak tedavide uygulanan 2Cd-A yüksek yanıt oranı ile etkili bir ajandır.

Anahtar Kelimeler: Kladribin, Prognoz, Saçlı Hücreli Lösemi

\section{Giriş}

Saçlı Hücre Lösemi(SHL) tüm lösemilerin $\% 2$ 'sini oluşturan, nadir hematolojik maligniteler arasında yer alır (1). Düşük dereceli kronik bir lenfoprolifratif hastalık olan SHL, adını sitoplazmik saçsı çıkıntılara sahip olan malign B hücrelerinden almaktadır. Malign B hücrelerin kemik iliği, lenf nodu, dalak ve karaciğerde birikimi sonucunda sitopeni, organomegali, lenfadenopati kliniği gelişmektedir. Sonucunda hastalar halsizlik yorgunluk, kanama, sık enfeksiyon geçirme öyküsü, karında şişlik ve dolgunluk hissi, erken doyma, kilo kaybı ve ele gelen şişlik şikayetleri ile başvurmaktadır (2). Asemptomatik hastalar tedavisiz izlenirken, semptomatik hastalar için

\begin{tabular}{lc}
\hline & ORCID No \\
Senem MARAL & $0000-0003-4766-1861$ \\
Murat ALBAYRAK & $0000-0003-4025-741 X$ \\
Hacer Berna AFACAN ÖZTÜRK $0000-0001-9386-7604$ \\
Abdulkerim YILDIZ & $0000-0002-9596-4042$ \\
Pınar CÖMERT & $0000-0003-3829-289 X$ \\
Buğra SAĞLAM & $0000-0001-8342-990 X$ \\
Mesut TIĞLIOĞLU & $0000-0002-4111-2004$ \\
Merih Reis ARAS & $0000-0002-9161-5582$ \\
& \\
Başvuru Tarihi / Received: & 17.04 .2020 \\
Kabul Tarihi / Accepted : & 21.08 .2020 \\
Adres / Correspondence : & Senem MARAL \\
Ankara Dışkapı Y1lırım Beyazıt Eğitim Araştırma Hastanesi, Şehit Halis \\
Ömer Cad. Altındağ /Ankara \\
\multicolumn{2}{l}{ e-posta / e-mail } \\
\hline
\end{tabular}

\begin{abstract}
Hairy cell leukemia (HCL), which is a rare chronic lymphoproliferative disease, progresses with relapses and remissions. With the introduction of purine analogues (PA) in the treatment, significant improvements have been achieved in the prognosis and survival of patients. In this study, we investigated the effect of PA on relapse and survival in the first line treatment with two different protocols. We retrospectively analyzed 20 HCL patients who treated with PA between 2009-2019. We compared the patients who were treated with single cycle PA and two cyclic consecutive PA treatment according to clinical features at the time of diagnosis, laboratory findings, response and relapse rates. Complete Remission (CR) and Partial Remission (PR) were achieved with equal rates in both groups (90\% and $10 \%$, resp.). Relapse was observed in one patient in each group during the 69 months of median follow-up time. A patient who was treated with one cycle PA was exitus due to non-disease cause. The superiority of two consecutive cycle 2Cd-A administration could not be demonstrated in relation to the response and relapse rates. 2Cd-A is highly effective agent as a first-line treatment option with a high response rate.
\end{abstract}

Keywords: Cladribine, Prognosis, Hairy Cell Leukemia

tedavi gereksinimi doğmaktadır $(3,4)$.

Özellikle purin analoglarının (PA) kullanıma girmesi ile hastalığın tedavisinde olumlu gelişmeler elde edilmiştir. Kladribin (2-CdA) ülkemizde yaygın olarak kullanılan bir PA'dır. Literatür verileri 2-CdA monoterapisi ile $\% 90$ üzerinde tam yanıt oranı elde edilmekle birlikte, elde edilen yanıtın korunamadığını göstermektedir $(5,6)$. İlk basamakta PA tedavisine yanıt alınan hastalarda bir süre sonra nüks nedeni ile tedavi ihtiyac1 gerekmektedir (7-10). Bu hastalarda halen kür sağlanamamakta, yaşam boyu relaps ve remisyonlarla seyreden klinik izlenmektedir. Çalışmamızda ilk basamak tedavide kullanılan 2$\mathrm{CdA}$ monoterapisinin iki farklı protokol ile verilmesinin yanıt ve nüks oranı üzerine etkisini araştırdık.

\section{Gereç ve Yöntem}

Kliniğimizde 2009-2019 y1lları arasında SHL tanıs1 ile takip edilen 24 hastadan, ilk basamakta PA ile tedavi edilen 20 vakayı retrospektif olarak inceledik. Bunlardan tek siklus 2-CdA uygulanan hastalar ile iki siklüs ardışık 2-CdA tedavisi alan hasta gruplarını yanıt ve nüks oranları açısından karşılaştırdık. İki hasta grubunun demografik özellikleri, tanı anındaki başvuru şikayeti, fizik muayene bulguları ve laboratuvar değerleri incelendi. 
SHL tanıs1 Dünya Sağlık Örgütü kriterlerine göre kemik iliği veya perifer kandan yapılan morfolojik ve akım sitometrik yöntemlere göre konmuştur (11). Tedavi kararı alınan hastalarda sitopeni varlığ $\left(\mathrm{hb}<11 \mathrm{gr} / \mathrm{dl}, \quad w b c<1000 / \mathrm{mm}^{3}\right.$, plt $<100000 / \mathrm{mm}^{3}$ ) sık enfeksiyon geçirme öyküsü, masif organomegali ve konstitusyonel semptomların varlığı göz önünde bulundurulmuştur (5). Ardış1k iki kür tedavi alan hastalar ilk kür sonrası yanıt değerlendirmesi yapılmaksızın 3 ay içerisinde 2. siklus 2-CdA tedavisi uyguland. Yanıt değerlendirmesi için tüm hastalara son tedavi bitiminden 3-6 ay sonra kemik iliği aspirasyon ve biyopsi ile ultrason görüntüleme yapıldı. Tam yanıtlı (TY) hastalar değerlendirilirken; sitopeninin düzelmesi, organomegali ve lenfadenopatide gerileme, periferde saçlı hücre izlenmemesi kriterlerinin hepsini karşılaması göz önünde bulundurulmuştur. Kısmi yanıt (KY) ise kemik iliği ve periferde saçlı hücre sayısında $\% 50$ oranda azalma, sitopenide düzelme, organomegali ve LAP boyutunda $\% 50$ gerileme olarak belirlenmiştir.

İki grup tedavi sonrası nötropeni süresi, nötropenik ateş atağı geçirme öyküsü, granulosit stimule edici faktör (GCSF) kullanımı açısından ayrica incelendi.
18.06.2019 tarih ve 65/14 sayılı etik kurul onay1 Ankara Dışkapı Yıldırım Beyazıt Eğitim ve Araştırma Hastanesi Klinik Araştırmalar Etik Kurulu Başkanlığı'ndan alınmıştır.

\section{Bulgular}

Çalışmaya dahil edilen $(\mathrm{n}=20)$ hastaların \%30'u kadın (n=6), \%70'i erkek $(n=14)$ cinsiyete sahipti. Vakaların yaşları 34-79 arasında değişmekte ve yaş ortalaması $50.55 \pm 11.80$ olarak saptanmıștır. Hastaların \%70'inde halsizlik $(n=14), \% 25$ 'inde karında dolgunluk $(\mathrm{n}=5)$ ve $\% 35$ 'unda $\mathrm{B}$ semptomu $(\mathrm{n}=7)$ tanı anındaki sikayetler arasında yer almaktadır. Ayrıca 3 hasta (\%15), herhangi bir şikayet olmaksızın kan tablosundaki düşüklük nedeni ile hematoloji bölümüne yönlendirilmesi sonucunda tanı almıştır. Splenomegali hastaların tümünde tanı anında saptanırken, 1 hastada periferal lenfadenopati saptanmıştır. Hastaların tanı anındaki demografik ve klinik özellikleri Tablo 1 'de yer almaktadır. Detaylı laboratuvar verileri Tablo 2'de yer almaktadır.

Tablo 1. Demografik veriler

\begin{tabular}{|c|c|c|c|}
\hline Parametre & Grup 1, n=10 (\%) & Grup 2, n=10 (\%) & Toplam, $\mathrm{n}=\mathbf{2 0}(\%)$ \\
\hline \multicolumn{4}{|l|}{ Cinsiyet } \\
\hline Kadın & $2(\% 20)$ & $4(\% 40)$ & $6(\% 30)$ \\
\hline $\operatorname{Erkek}(\%)$ & $8(\% 80)$ & $6(\% 60)$ & $14(\% 70)$ \\
\hline Yaş (ortalama $\pm s s)$ & $53.50 \pm 4.18$ & $47.46 \pm 3.16$ & $50.55 \pm 11.80$ \\
\hline Komorbidite & $3(\% 30)$ & $1(\% 10)$ & $4(\% 20)$ \\
\hline \multicolumn{4}{|l|}{ Başvuru şikayeti } \\
\hline Halsizlik & $8(\% 80)$ & $6(\% 60)$ & $14(\% 70)$ \\
\hline Karında dolgunluk hissi & $1(\% 10)$ & $4(\% 40)$ & $5(\% 25)$ \\
\hline Konstitüsyonel semptomlar & $5(\% 50)$ & $2(\% 20)$ & $7(\% 35)$ \\
\hline Asemptomatik & $1(\% 10)$ & $2(\% 20)$ & $3(\% 15)$ \\
\hline \multicolumn{4}{|l|}{ Kemik iliği incelemesi } \\
\hline Fibrozis skoru 1 & $0(\% 0)$ & $4(\% 40)$ & $4(\% 20)$ \\
\hline Fibrozis skoru 2 & $5(\% 50)$ & $4(\% 40)$ & $9(\% 45)$ \\
\hline Fibrozis skoru 3 & $4(\% 40)$ & $1(\% 10)$ & $5(\% 25)$ \\
\hline Periferde saçlı hücre varlığı & $2(\% 20)$ & $3(\% 30)$ & $5(\% 25)$ \\
\hline Periferal LAP varlığı & $1(\% 10)$ & $0(\% 0)$ & $1(\% 5)$ \\
\hline \multicolumn{4}{|l|}{ Tedavi Öncesi (ortalama \pm ss) } \\
\hline Dalak boyutu, mm & $166.9 \pm 34.01$ & $195.7 \pm 42.8$ & $181.10 \pm 40.43$ \\
\hline Karaciğer boyutu,mm & $155.7 \pm 10.0$ & $174.9 \pm 38.4$ & $165.30 \pm 29.40$ \\
\hline \multicolumn{4}{|l|}{ Tedavi sonrası (ortalama \pm ss) } \\
\hline Dalak boyutu,mm & $132.0 \pm 12.65$ & $136.7 \pm 26.38$ & $134.60 \pm 20.22$ \\
\hline \multicolumn{4}{|l|}{ Tedavi sonrası } \\
\hline GCSF desteği ihtiyacı & $6(\% 60)$ & $7(\% 70)$ & $13(\% 65)$ \\
\hline FEN atağı & $6(\% 60)$ & $6(\% 70)$ & $12(\% 60)$ \\
\hline
\end{tabular}

Tanısal amaçlı hastaların tümüne kemik iliği biyopsisi yapılmış, ayrıca 8 hastada kemik iliği aspirasyon örneğinden akım sitometrik yöntem ile tanı doğrulanmıştır. BRAF-V600E mutasyonu 3 hastada araştırılmış ve pozitif bulunmuştur. Tanısal amaçlı bazı vakalara kemik iliği örneğinde TRAP 
$(\mathrm{n}=8)$, aneksin $(\mathrm{n}=6)$ ve retikülin $(\mathrm{n}=20)$ histokimyasal boyamaları uygulanmıştır. Varyant SHL tanısı alan hastamız bulunmamaktadır.

Hastalarımızın tümünde ilk basamak tedavide seçilen PA, Kladribin (2-CdA) olduğu gözlenmiştir. Protokolde $0.10 \mathrm{mg} / \mathrm{kg} 7$ gün intravenöz(iv) veya subkutan(sk), $0.14 \mathrm{mg} / \mathrm{kg} 5$ gün iv şeklinde uygulanmıştır. Hastaların yarısı $(n=10)$ tek doz 2$\mathrm{CdA}$ monoterapisi alırken, diğer hastalar $(\mathrm{n}=10)$ ardışık iki doz 2-CdA monoterapisi almıştır.

Her iki grup için ilk basamak tedaviye TY oranı $\% 90, \mathrm{KY}$ oranı $\% 10$ ve yanıtlar her iki grupta eşit olarak değerlendirilmiştir. Hastalarımızın medyan takip süresi 69 aydır ve bu süre içerisinde nüks izlenen 2 hasta olup, 1 hasta SHL dişı nedenle eks olmuştur (Tablo 3).

Uzamış nötropeni vakaların \%65'inde $(n=13)$ izlenmiş ve tümünde GCSF desteğine başvurulmuştur. Nötropenik olduğu süreçte febril nötropeni (FEN) atağ1 nedeni ile başvuran hasta oranı \% $60 \quad(\mathrm{n}=12)$ olarak belirlenmiştir (Tablo 2).

Tablo 2. Laboratuvar özellikleri

\begin{tabular}{|c|c|c|c|}
\hline Parametre & Grup 1 & Grup 2 & Toplam \\
\hline \multicolumn{4}{|c|}{ Tedavi Öncesi Hemogram, Ortanca (min-max) } \\
\hline Hemoglobin, gr/dl & $7.55(4.1-15.9)$ & $9.45(6.9-13.2)$ & $9.2(4.1-15.9)$ \\
\hline Beyaz Küre, $\mathbf{x 1 0} / \mu \mathrm{L}$ & $3050(1070-2630)$ & $2515(1120-13900)$ & $2735(1030-26300)$ \\
\hline Nötrofil, $\times 10^{3} / \mu \mathrm{L}$ & $760(130-8410)$ & $815(160-2700)$ & $8150(130-8410)$ \\
\hline Lenfosit, $x 10^{3} / \mu \mathrm{L}$ & $1520(810-12100)$ & $1195(800-10500)$ & $1430(800-12100)$ \\
\hline Monosit, $x 10^{3} / \mu \mathrm{L}$ & $100(0-5440)$ & $250(20-6100)$ & $100(0-610)$ \\
\hline Trombosit, $x 103 / \mu \mathrm{L}$ & $47500(16000-130000)$ & $69000(19000-173000)$ & $56500(16000-175000)$ \\
\hline \multicolumn{4}{|c|}{ Tedavi Sonrası Hemogram, Ortanca (min-max) } \\
\hline Hemoglobin, gr/dl & $14.5(10.9-17.0)$ & $13.2(10.9-16.0)$ & $13.65(10.9-17.0)$ \\
\hline Beyaz Küre, $\times 10^{3} / \mu \mathrm{L}$ & $5035(4360-7260)$ & $3915(400-9600)$ & $5035(400-9600)$ \\
\hline Nötrofil, $x 10^{3} / \mu \mathrm{L}$ & $3175(1210-5600)$ & $2940(100-7000)$ & $3175(100-7000)$ \\
\hline Lenfosit, $x 10^{3} / \mu \mathrm{L}$ & $1480(730-3200)$ & $420(200-1400)$ & $1000(200-3200)$ \\
\hline Monosit, $\mathbf{x 1 0} / \mu \mathrm{L}$ & $455(280-1430)$ & $350(0-940)$ & $400(0-1430)$ \\
\hline Trombosit, $\times 10^{3} / \mu \mathrm{L}$ & $185000(92000-254000)$ & $122500(72000-225000)$ & $157000(72000-254000)$ \\
\hline \multicolumn{4}{|c|}{ Biyokimyasal Değerler, Ortanca (min-max) } \\
\hline Vitamin B12, ng/L & $307(84-473)$ & $180(86-615)$ & $218(84-615)$ \\
\hline Ferritin, ug/L & $197(20-492)$ & $91.5(24-300)$ & $113(20-493)$ \\
\hline LDH, U/L & $154(130-385)$ & $200(115-258)$ & $186(118-389)$ \\
\hline Sedimantasyon, $\mathrm{mm} / \mathrm{saat}$ & $70.5(7-107)$ & $22.5(7-62)$ & $26(7-107)$ \\
\hline
\end{tabular}

Tablo 3. Yanıt, nüks ve yaşamsal veriler durumu

\begin{tabular}{lcc}
\hline Parametre & $\begin{array}{c}\text { Grup1 } \\
(\mathbf{n}=\mathbf{1 0})\end{array}$ & $\begin{array}{c}\text { Grup 2 } \\
(\mathbf{n}=\mathbf{1 0})\end{array}$ \\
\hline Yanıt & & \\
$\quad$ Tam yanıt & 9 & 9 \\
$\quad$ Kısmı yanıt & 1 & 1 \\
Medyan takip süresi, ay & 69 & 69 \\
Takip süresi, ay (min-max) & $69(16-101)$ & $57(35-96)$ \\
Nüks olan vaka & 1 & 1 \\
Nükse kadar geçen süre, ay & 25 & 31 \\
Eksitus & 1 & 0 \\
\hline
\end{tabular}

\section{Tartışma}

Literatür verileri ile karşılaştırıldığında tedavi alan SHL hastalarımız demografik, morfolojik ve patolojik özellikler açısından benzer özellikler sergilemektedir (12,13). Klinik çalışmalar 1/4 hastanın rastlantısal tanı aldığını bildirmektedir. Merkezimizde takip ettiğimiz vakaların \%15'inin asemptomatik olup, rastlantisal tanı almasına rağmen tedavi gereksinimi olduğunu gözlemledik. Splenomegali hastalarımızda en sık saptadığımız fizik muayene bulgusu iken halsizlik en sık başvuru şikayetidir. Başvuru anında hemogram bulgularından en sık pansitopeni görülmektedir. Medyan sedimantasyon değerinin laboratuvar aralığımızın üstünde izlenmesi, lokopeni sonucunda sık geçirilen enfeksiyon kliniği ile ilişkilendirilmiştir.

Hastalarımızın tedavi ihtiyacı ortalama 6. dekatta olmaktayd. Fakat genç yaşta tedavi alan hastalarımız da vardır. En genç tedavi ettiğimiz hastamız 34 yaşındadır. Literatürde 40 yaş altı hastaların verilerinin sunulduğu çalışmalarda dikkati çeken bu hasta grubunun yanıt süresinin kısa olmasıdır (14). 40 yaş altı tedavi alan iki hastamızda tam yanıt elde edilmiş ve yanıt korunmaktadır.

İlk basamak tedavide toplam yanıt oran (TY+KY) \%90'ın üzerinde ve TY oranı yaklaşık $\%$ k0ydedilmektedir $(9,10)$. Çalıșmamızda gruplar arasında yanıt açısından farklılık olmamakla birlikte literatür verileri ile benzer bulunmuştur. Klinik pratikte, SHL tedavisinde $2 \mathrm{Cd}$ A iv infüzyon ve sk olmak üzere 2 farklı şekilde uygulanmakta ve uygulanma şeklinin etkinlik açısından farklılık olmadığını göstermiştir $(15,16)$. Vakalarımız sağ kalım ve nüks açısından incelendiğinde $2 \mathrm{Cd}$-A tek siklus uygulanması ile ardışık iki siklus uygulanmasının yanıt ve prognoz açısından farklılık oluşturmadığı görülmüştür.

Else ve arkadaşlarının çalışmasında ilk basamakta PA ile tedavi edilen hastaların \%4'ünde 
yanıtsızlık, \%20 sinde kısmi yanıt izlenmiştir $(9,10)$. Ayrica $2 \mathrm{Cd}-\mathrm{A}$ ile tedavi sonrasında 10 yillık izlemde hastaların \%30-40 oranda nüks ettiği ve yeniden tedavi ihtiyacı doğduğu gösterilmiştir (710). Nüks vakalarda 2-CdA ile yeniden tedavi uygulandığı takdirde ortalama \%40-75 oranda tam remisyon elde edilmektedir (17). Çalışmamızda takip süremiz içerisinde her iki gruptan birer hastamızda nüks gelişmiş ve yeniden aynı ajan ile tedavi uygulanmıştır. Nüks olan 2 hastamızda tedaviden 2 yıl sonra gelişmiş ve birisinde ilk basamak tedavi ile KY elde edildiği görülmüştür. TY elde eden hastaların, KY elde edenlere göre anlamlı derecede daha uzun medyan hastalıksız sağkalım gösterilmiştir (18). Nüks nedeni ile yeniden tedavi alan hastalarımızda TY elde edilmiştir.

Tedavi edilen hastalarımızın anemi ve trombositopeni değerlerinin düzeldiğini gözlenmiştir. Lökopeni açısından tek siklus tedavi alan hastalarda lokosit düzeyi ilk 3 aylık period içerisinde normal sınırlara gelirken, iki siklus tedavi alan hasta grubunda uzamış lökopeni ve nötropeni gözlemlenmiştir. $\mathrm{Bu}$ durum hastalara uygulanan ardışık PA ile ilişkilendirilmiştir. Uzamış nötropeni iki siklus uygulanan hastalarda daha sik rastlanmasına rağmen her iki grupta GCSF ihtiyacı ve FEN atağı sayılarında farklılık izlenmemiştir.

2Cd-A tedavisinin uzun dönemde sekonder malignite gelişimine neden olabileceği konusunda tartışmalı veriler mevcuttur $(19,20)$. Medyan 5 yılın üzerindeki takip süremiz içerisinde hastalarımızda sekonder malignite gelişimi gözlenmemiştir.

Hematolojinin nadir görülen hastalıklardan olması nedeniyle az sayıda hastanın çalışmaya dahil edilmesi çalışmamızın kısıtlayıcı özelliğidir. Tek merkez verilerini kapsayan az sayıdaki veriler için istatistiksel olarak anlamlı yanıt oranları hesaplanamamıştır. Ayrıca çalışmamızın retrospektif dizaynı nedeni ile tanısal amaçlı uygulanması gereken akım sitometrik incelemeler ve genetik mutasyon taraması her vakada gerçekleştirilememiştir. Hastalık prognozunda önemli olduğu gösterilen minimal kalıntılı hastalık değerlendirilmesi teknik yetersizlikler nedeni gösterilememiştir.

Sonuç olarak ilk basamak tedavide uygulanan 2Cd-A, yüksek yanıt oranı ile etkili bir ajandır. Ardışık iki siklus 2Cd-A uygulanmasının yanıt oranı ve hastalıksız sağ kalım ilişkili üstünlügü gösterilememiştir. Geniş sayıda vakanın dahil edildiği klinik çalışmaların sunulması verilemizin güçlendirilmesi açısından yol gösterici olacaktır.

Etik Kurul Onayı: Ankara Dışkapı Yıldırım Beyazıt Eğitim ve Araştırma Hastanesi Klinik Araştırmalar Etik Kurulu Başkanlığı'ndan
18.06.2019 tarih ve 65/14 say1lı etik kurul onay1 alınmıştır.

\section{Kaynaklar}

1. Bouroncle BA, Wiseman BK, Doan CA. Leukemic reticuloendotheliosis. Blood. 1958;13(7):609-30.

2. Golomb HM, Catovsky D, Golde DW. Hairy cell leukemia: A clinical review based on 71 cases. Ann Intern Med. 1978;89(5 Pt 1):677-83.

3. Savoie L, Johnston JB. Hairy cell leukemia. Curr Treat Options Oncol. 2001;2(3):217-24.

4. Allsup DJ, Cawley JC. The diagnosis and treatment of hairy cell leukemia. Blood Rev. 2002;16(4):255-62.

5. Saven A, Burian C, Koziol JA, Piro LD. Long-term followup of patients with hairy cell leukemia after cladribine treatment. Blood. 1998;92(6):1918-26.

6. Tadmor T, Polliack A. Epidemiology and environmental risk in hairy cell leukemia. Best Pract Res Clin Haematol. 2015;28(4):175-9.

7. Goodman GR, Burian C, Koziol JA, Saven A. Extended follow-up of patients with hairy cell leukemia after treatment with cladribine. J Clin Oncol. 2003;21(5):891-96.

8. Maloisel F, Benboubker L, Gardembas M, et al. Long-term outcome with pentostatin treatment in hairy cell leukemia patients: a French retrospective study of 238 patients. Leukemia. 2003;17(1):45-51

9. Else M, Ruchlemer R, Osuji N, et al. Long remissions in hairy cell leukemia with purine analogs: a report of 219 patients with a median follow-up of 12.5 years. Cancer. 2005;104(11):2442-8.

10. Else M, Dearden CE, Matutes E, et al. Long-term follow-up of 233 patients with hairy cell leukaemia, treated initially with pentostatin or cladribine, at a median of 16 years from diagnosis. Br J Haematol. 2009;145(6):733-40.

11. Swerdlow SH, Campo E, Pileri SA, et al. The 2016 revision of the World Health Organization classification of lymphoid neoplasms. Blood. 2016;127(20):2375-90.

12. Smith A, Howell D, Patmore R, Jack A, Roman E. Incidence of haematological malignancy by sub-type: a report from the Haematological Malignancy Research Network. Br J Cancer. 2011;105(11):1684-92.

13. Grever MR. How I treat hairy cell leukemia. Blood. 2010;115(1):21-8.

14. Rosenberg JD, Burian C, Waalen J, Saven A. Clinical characteristics and long-term outcome of young hairy cell leukemia patients treated with cladribine: a single-institution series. Blood. 2014;123(2):177-83.

15. Juliusson G, Heldal D, Hippe E, et al. Subcutaneous injections of 2-chlorodeoxyadenosine for symptomatic hairy cell leukemia. J Clin Oncol. 1995;13(4):989-95.

16. Robak T, Błasińska-Morawiec M, Krykowski E, et al. 2chlorodeoxyadenosine (2-CdA) in 2-hour versus 24-hour intravenous infusion in the treatment of patients with hairy cell leukemia. Leuk Lymphoma. 1996;22(1-2):107-11.

17. Tallman MS. Current treatment strategies for patients with hairy cell leukemia. Rev Clin Exp Hematol. 2002;6(4):389450

18. Dearden CE, Matutes E, Hilditch BL, Swansbury GJ, Catovsky D. Long-term follow-up of patients with hairy cell leukaemia after treatment with pentostatin or cladribine. $\mathrm{Br}$ J Haematol. 1999;106(2):515-9.

19. Au WY, Klasa RJ, Gallagher R, Le N, Gascoyne RD, Connors JM. Second malignancies in patients with hairy cell leukemia in british columbia: a 20-year experience. Blood. 1998;92(4):1160-4.

20. Hisada M, Chen BE, Jaffe ES, Travis LB. Second cancer incidence and cause-specific mortality among 3104 patients with hairy cell leukemia: a population-based study. J Natl Cancer Inst. 2007;99(3):215-22. 